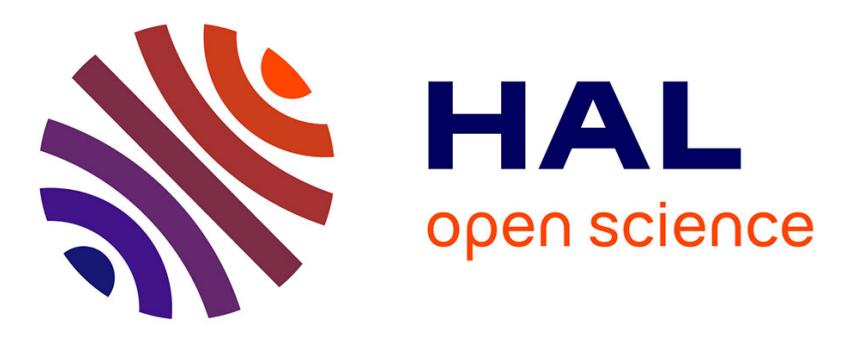

\title{
Evidence of a water $\delta 180$ negative shift driven by intensive deep CO2 upflow at Shiwaga gas field (Rungwe, Tanzania)
}

Laurent Bergonzini, Manuëlla Frédérique, Dominique Delalande, Fabrizio

Gherardi, Pierre-Etienne Mathé, Amos Majule, David Williamson

\section{To cite this version:}

Laurent Bergonzini, Manuëlla Frédérique, Dominique Delalande, Fabrizio Gherardi, Pierre-Etienne Mathé, Amos Majule, et al.. Evidence of a water $\delta 18 \mathrm{O}$ negative shift driven by intensive deep CO2 upflow at Shiwaga gas field (Rungwe, Tanzania). Environmental Earth Sciences, 2018, 77 (13), pp.497. $10.1007 / \mathrm{s} 12665-018-7665-2$. hal-01833173

\section{HAL Id: hal-01833173 https://hal.science/hal-01833173}

Submitted on 7 Nov 2018

HAL is a multi-disciplinary open access archive for the deposit and dissemination of scientific research documents, whether they are published or not. The documents may come from teaching and research institutions in France or abroad, or from public or private research centers.
L'archive ouverte pluridisciplinaire HAL, est destinée au dépôt et à la diffusion de documents scientifiques de niveau recherche, publiés ou non, émanant des établissements d'enseignement et de recherche français ou étrangers, des laboratoires publics ou privés. 


\title{
Evidence of a water $\delta^{18} 0$ negative shift driven by intensive deep $\mathrm{CO}_{2}$ upflow at Shiwaga gas field (Rungwe, Tanzania)
}

\author{
Laurent Bergonzini ${ }^{1} \cdot$ Manuëlla Delalande-Le Mouëllic ${ }^{1,2}$ (D) Fabrizio Gherardi ${ }^{3} \cdot$ Pierre-Etienne Mathe $^{4}$. \\ Amos Majule $^{5} \cdot$ David Williamson $^{6}$
}

\begin{abstract}
Located on the flank of Ngozi volcanoes (Tanzania), the Shiwaga gas field is a spot of intense $\mathrm{CO}_{2(\mathrm{~g})}$ emanations. Physicochemical measurements on different types of waters (rivers, puddles, and springs) as water and gas sampling were discontinuously performed over 10 years for equilibrated partial $\mathrm{CO}_{2}$ pressure calculations and stable isotopic analyses. The most striking result shows that meteoric $\mathrm{H}_{2} \mathrm{O}$ and deep originated $\mathrm{CO}_{2(\mathrm{~g})}$ exchanges are responsible for a negative ${ }^{18} \mathrm{O}$-shift of the studied waters in relation with waters electrical conductivity, $\mathrm{pH}$, and $p \mathrm{CO}_{2}$ eq changes. In spring waters, a maximum shift of $-11.2 \%$ in $\delta^{18} \mathrm{O}$ was observed and $p \mathrm{CO}_{2}$ eq values up to $1196 \mathrm{mbar}$ were computed. Although this trend has already been reported around the world, such extended shift is rarely measured and requires an important amount of $\mathrm{CO}_{2(\mathrm{~g})}$, with a $\mathrm{CO}_{2(\mathrm{~g})} /$ $\mathrm{H}_{2} \mathrm{O}$ ratio up more than $0.5 \mathrm{~mol} / \mathrm{mol}$. This approach is useful to better understand the hydro-geochemical processes involved in such environments. Moreover, this study evidences that an inventory as a monitoring of these gas fields are needed for the management of natural hazards and local resources.
\end{abstract}

\section{Introduction}

Natural $\mathrm{CO}_{2}$, degassing from geological sources, is known from active and dormant volcanoes, submarine volcanism, major fault zones, geothermal systems, and thermal decomposition of organic matter, and is an important source of

Manuëlla Delalande-Le Mouëllic

manuella.delalande-le-mouellic@univ-reunion.fr

1 GEOPS, Université Paris-Sud, CNRS, Université ParisSaclay, 91405 Orsay, France

2 Université de la Réunion, Institut de Physique du Globe de Paris, Sorbonne Paris Cité, CNRS, UMR 7154 Laboratoire Géosciences Réunion, 97744 Saint-Denis, France

3 CNR, Istituto di Geoscienze e Georisorse, Via G. Moruzzi, 1, 56124 Pisa, Italy

4 Aix-Marseille Université, CNRS, IRD, INRA, Coll France CEREGE, Aix en Provence, France

5 IRA, University of Dar es Salaam, P.O. Box 35097, Dar es Salaam, Tanzania

6 IRD, Sorbonne Université, UMR 7159 LOCEAN, UPMC, MNHN, CNRS, IRD-IPSL, ICRAF, P.O. Box 30677-00100, Nairobi, Kenya non-anthropogenic $\mathrm{CO}_{2}$ (Hards 2005). All along the East African Rift System (EARS), many $\mathrm{CO}_{2}$ gas emanations have been recognized (Darling 1998). They can be associated with water in $\mathrm{CO}_{2}$-rich bubbling springs (either hot or cold) or occur as dry gas vent. They are currently linked with active and Quaternary volcanism and with active faults. Dry gas vents can be identified if they are located in depression where $\mathrm{CO}_{2}$, invisible and denser than surrounding air, accumulates and can sometimes reach lethal concentrations. Usually $\mathrm{CO}_{2}$ rapidly dissipates in the air especially under windy weather. Nevertheless, when $\mathrm{CO}_{2}$ in the atmosphere is $>1 \mathrm{vol} \%$, it becomes toxic for humans and animals. This type of vents constitutes a natural hazard in many volcanic areas (Sorey et al. 2000; Hards 2005) and often kills in East Africa (Vaselli et al. 2002; de Moor et al. 2013). Such phenomena had already been reported in the North of Lake Kivu on the Nyiragongo flank of the Virunga Volcanic Province (Vaselli et al. 2002; Smets et al. 2010), where they are called "Mazuku", which in Swahili means "Evil's winds". Volcanic $\mathrm{CO}_{2}$ vents were also recognized in the North of Lake Nyasa in the Rungwe Volcanic Province (RVP) on the Ngozi, Rungwe and Kiejo volcano flanks where $\mathrm{CO}_{2}$ gas is 
conditioned and commercialized especially for soda industries (Delalande et al. 2011; Fontijn et al. 2012).

This paper outlines field measurements and water $\left(\delta^{18} \mathrm{O}\right.$ and $\left.\delta^{2} \mathrm{H}\right)$ as well as $\mathrm{CO}_{2}$ gas $\left(\delta^{13} \mathrm{C}\right.$ and $\left.\delta^{18} \mathrm{O}\right)$ stable isotopic signatures from the Shiwaga gas field, located on the South-West Ngozi flank of the RVP of Tanzania. The investigation was discontinuously carried out during the last 10 years, with the aim to better understanding (1) the nature and degassing regime of this field, (2) waters and gas geochemical interactions, and (3) the origin of the atypical water isotopic composition.

\section{The Shiwaga gas field}

The Shiwaga gas field $\left(33.50^{\circ} \mathrm{E}-9.05^{\circ} \mathrm{S} ; 1710-1715 \mathrm{~m}\right.$ a.s.l.; Fig. 1) is located at the intersection of the Shiwaga River and tectonic fault on the West lowland of the Shiwaga Hill in the SW sector of Ngozi volcano. This volcano and those of Rungwe and Kiejo are the largest volcanoes of the RVP. Its position is strongly controlled by the tectonic activity, as it is located at the junction of the three rift branches of Malawi, Rukwa, and Usangu
Fig. 1 a Location and b schematic topographic profile of the Shiwaga gas field. a The black star marks the location of Shiwaga gas field. White circles indicate the main volcanoes (K: Kiejo, R: Rungwe, and $\mathrm{N}$ : Ngozi) and continuous black lines trace the main fault systems ( $L F$ Livingstone Fault and $M F$ Mbaka Fault). Lakes Malawi (LM) and Ngozi (LN) are figured with a gray shape and their acronym. b " $\mathrm{S}$ ", "R", "P", and "D" mean "Spring", "River", "Puddle", and "Dry gas vent", respectively

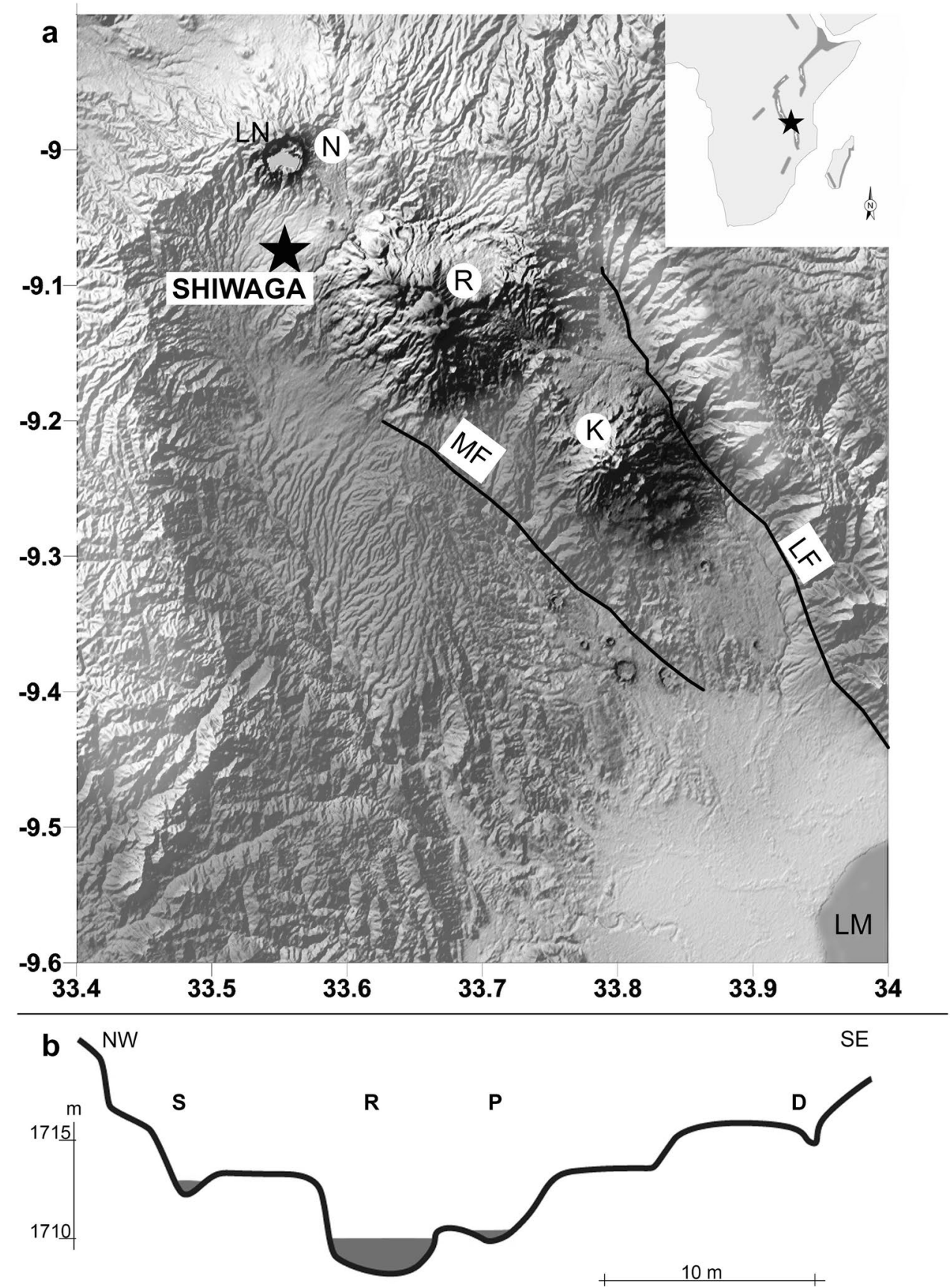


grabens. It culminates around $2500 \mathrm{~m}$ a.s.l., and shows a $3 \mathrm{~km}$ in diameter caldera, occupied by Lake Ngozi (around 2060 m a.s.l.; Delalande-Le Mouëllic et al. 2015). The Ngozi volcano had undergone at least two major eruptions in the Holocene, responsible for both the caldera formation and important ash deposition at regional scale (Fontijn et al. 2010, 2012). In the RVP, the last eruptive activity was characterized by the Sarabwe and Fiteko spatter scoria cones on the Kiejo flank (dated at 1800 AD; Harkin 1960). A current expression of the RVP magmatic activity at depth is the presence of numerous dry gas vents and hot springs (Branchu et al. 2005; Delalande et al. 2011; de Moor et al. 2013). The Shiwaga River drains an important catchment of the Ngozi flank and originates at about $2300 \mathrm{~m}$ of altitude. The Shiwaga stream is around $1 \mathrm{~m}$ large and less than $0.5 \mathrm{~m}$ deep in its center. Its flow rate is a few dozen liter per second with a high water level at the end of the rainy season (May-June) and low water level at the end of the dry period (October-November). On the riverbank, an important deposit of Ngozi ash outcrop forms the Shiwaga Hill. The Shiwaga gas field is mainly characterized by specific open scrubby vegetation and the absence of any riparian forest.

Located at the bottom of the Shiwaga Valley, the Shiwaga gas field corresponds to intense scattered gas emanations. These activities are evidenced by (1) vigorous bubbling across the Shiwaga River and (2) water and/or gas emergences located on the riverbanks (Fig. 1b). These emergences correspond to small springs (of few $\mathrm{l} \mathrm{h}^{-1}$ water flows) of "moffeta" type during the rainy season and noxious dry gas vents, of "mazuku" type during the dry season. This gas activity makes Shiwaga River looking like a bubbling Jacuzzi, producing important noise and foul fetid environment. An extremely high $\mathrm{CO}_{2}$ flux emission of higher than $100 \mathrm{~kg} \mathrm{~m}^{-2} \mathrm{~h}^{-1}$ was measured in the intensive bubbling zone of the river (RESON, unpublished data). These gas emanations are known to cause deaths of natives as well as animals passing nearby. Numerous dead animals (birds, rodents, reptiles) were indeed found on the ground during our surveys. The hazardousness of the area is recognized from local witnesses and is at the origin of many legends and beliefs. The Shiwaga gas emanations, as many other RVP sites, are mostly composed of $\mathrm{CO}_{2}$ (more than $95 \%$ up to 99\%; Ebinger et al. 1993; Delalande et al. 2008, 2011; Kraml et al. 2010; de Moor et al. 2013). High ${ }^{3} \mathrm{He} /{ }^{4} \mathrm{He}$ ratios measured in Lake Ngozi water $(\mathrm{R} / \mathrm{Ra}=8.3$; Delalande et al. 2008; Delalande-Le Mouëllic et al. 2015), RVP hydrothermal waters and gases (Barry et al. 2013), or volcanic RVP rocks (Hilton et al. 2011) evidence a gas mantle source and highlight plume-like ratios under the RVP. During the last decade, the RVP had been explored, investigated, and recognized for its promising geothermal potential (Kraml et al. 2010, 2014; Kalerkamp et al. 2010; Kabaka et al. 2016). A geophysical investigation located the hottest part $\left(\approx 230{ }^{\circ} \mathrm{C}\right)$ of the geothermal reservoir at about $2200 \mathrm{~m}$ below the Ngozi volcano surface (Kalerkamp et al. 2010) with a $p \mathrm{CO}_{2}$ of $15 \pm 4$ bar (Kabaka et al. 2016).

\section{Materials and methods}

Shiwaga gas field was investigated during several field surveys: September 2006, October 2007, April 2010, April and December 2012, and November 2013, corresponding either to dry and rainy seasons. Water $(n=28)$ and gas $(n=15)$ from (1) Shiwaga River, (2) riversides puddles, (3) "moffeta" springs, and (4) dry gas vents both located on the banks of the river were sampled (Fig. 1). Water samples were collected for field and stable isotopic composition measurements, while gases were sampled for stable isotopic analyses. They were named (Table 1$)$ as: $\mathrm{R}$ for River $(n=11), \mathrm{P}$ for Puddle $(n=12)$, S for Spring $(n=5)$, and D for Dry gas vent $(n=2)$ samples, followed by the sample number and the sampling dates (month/year).

Water temperature $(T)$, electrical conductivity (EC measured with a WTW, LF-330 electronic meter), $\mathrm{pH}$ (measured with a WTW pH315j electronic meter) and alkalinity (Alk, obtained by colorimetric titration) were measured in situ ( $n=28$; Table 1). Equilibrated partial $\mathrm{CO}_{2}$ pressure $\left(p \mathrm{CO}_{2}\right.$ eq expressed in mbar, Table 1) was calculated from $T, \mathrm{pH}$, and Alk using the equations of Plummer and Busenberg (1982) and considering that Alk $=[$ $\left.\mathrm{HCO}_{3}{ }^{-}\right]+2\left[\mathrm{CO}_{3}{ }^{2-}\right]+\left[\mathrm{OH}^{-}\right]$. Water samples collected in $15 \mathrm{ml}$ glass bottles were used for stable isotopic analyses $\left(\delta^{18} \mathrm{O}-\mathrm{H}_{2} \mathrm{O}\right.$ and $\left.\delta^{2} \mathrm{H}-\mathrm{H}_{2} \mathrm{O}\right)$. Gases were sampled directly from the bubbling sites and the dry gas vents using a funnel and small vacuum glass vial for analyzing $\mathrm{CO}_{2(\mathrm{~g})}$ isotope compositions $\left(\delta^{13} \mathrm{C}-\mathrm{CO}_{2(\mathrm{~g})}\right.$ and $\left.\delta^{18} \mathrm{O}-\mathrm{CO}_{2(\mathrm{~g})}\right)$. Isotope analyses were performed at GEOPS laboratory (University Paris-Saclay, France) by mass spectrometry with a Finnigan Deltaplus for $\delta^{18} \mathrm{O}-\mathrm{H}_{2} \mathrm{O}$ and $\delta^{2} \mathrm{H}-\mathrm{H}_{2} \mathrm{O}$ and a SIRA 10 for $\delta^{13} \mathrm{C}-\mathrm{CO}_{2(\mathrm{~g})}$ and $\delta^{18} \mathrm{O}-\mathrm{CO}_{2(\mathrm{~g})}$ (Table 1). Isotopic compositions are expressed in delta notation per mil $(\delta \%)$, vs. V-SMOW for hydrogen as oxygen and vs. V-PDB for carbon. The inter-laboratory analytical precision was 0.15 , 1.5 , and $0.2 \%$ or for $\delta^{18} \mathrm{O}, \delta^{2} \mathrm{H}$, and $\delta^{13} \mathrm{C}$, respectively.

\section{Results}

\section{Field measurements}

The measured $T, \mathrm{EC}, \mathrm{pH}$, and Alk showed large variations (Table 1; Fig. 2). The river water temperatures varied from 17.5 to $22.3{ }^{\circ} \mathrm{C}$, whereas those of the springs were slightly lower between 11.7 and $16.5^{\circ} \mathrm{C}$. The puddle water 


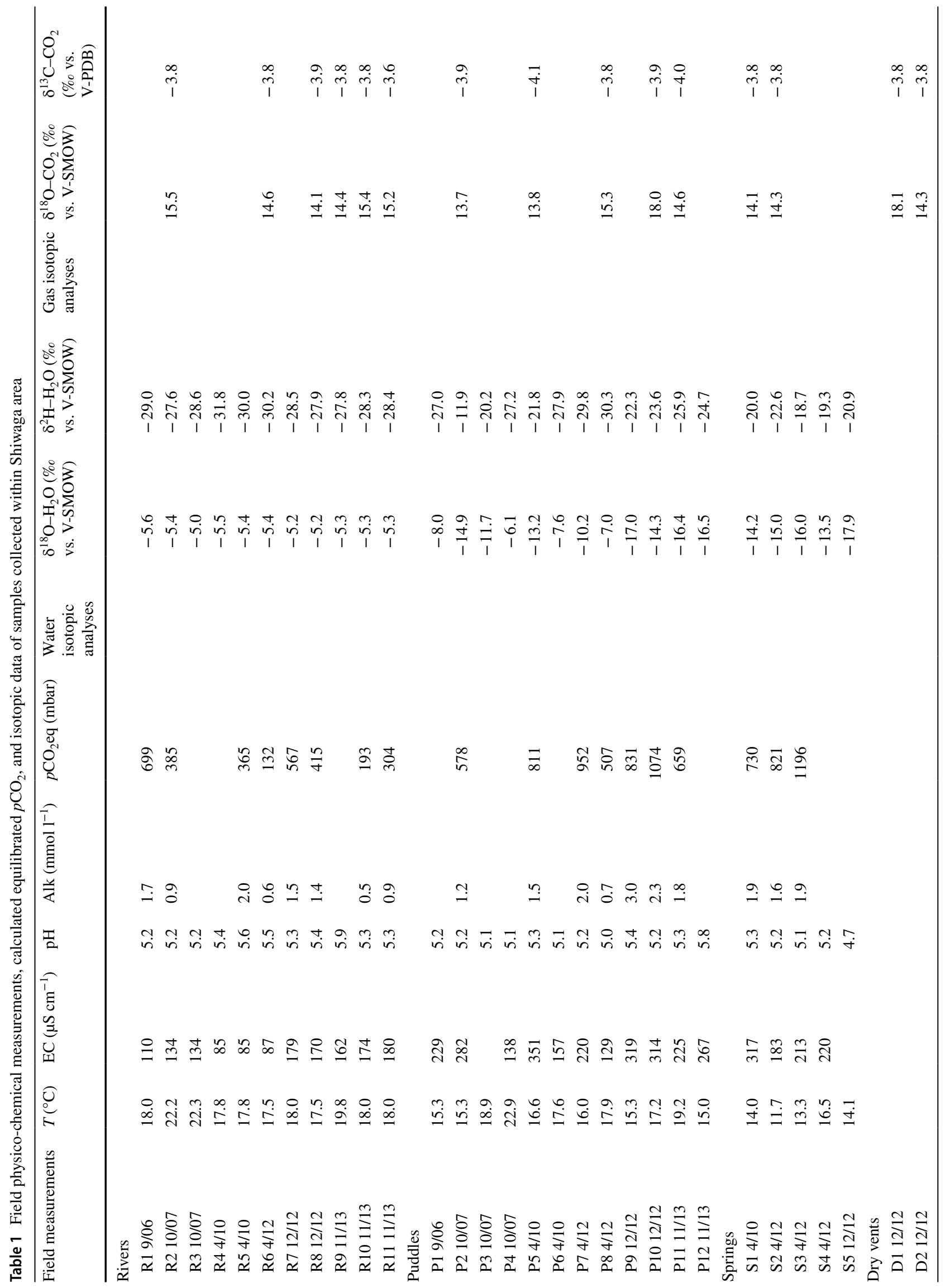



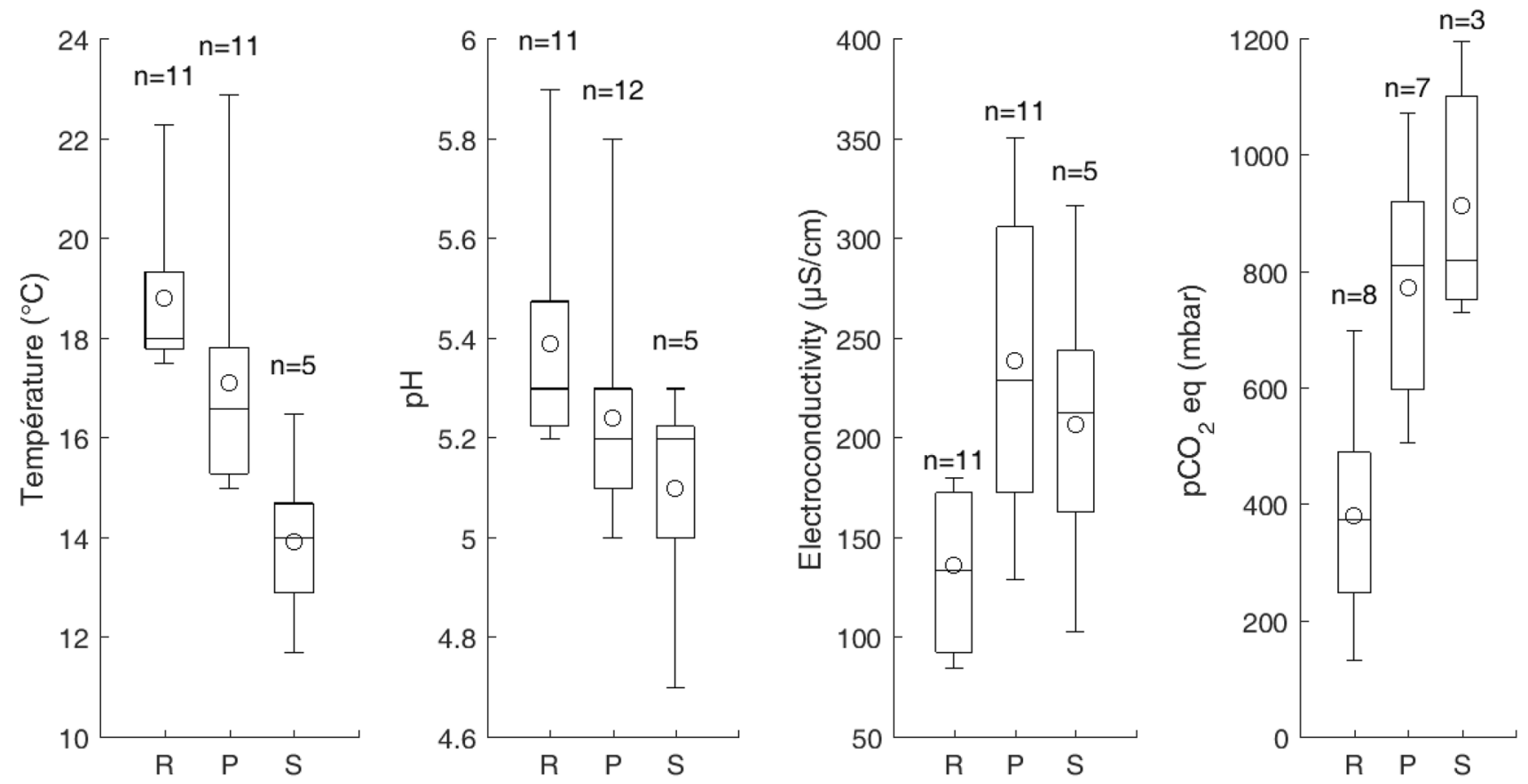

Fig. 2 Box plots [with: minimum, first-quartile, mean, median (open circle), third quartile and maximum] of temperature $\left({ }^{\circ} \mathrm{C}\right)$, $\mathrm{pH}$, electro-conductivity $\left(\mu \mathrm{S} \mathrm{cm}^{-1}\right)$, and equilibrated $p \mathrm{CO}_{2}(\mathrm{mbar})$ for river $(\mathrm{R})$, puddles $(\mathrm{P})$, and spring $(\mathrm{S})$ obtained at the Shiwaga gas field

temperatures were intermediate, between 15.0 and $22.9^{\circ} \mathrm{C}$. The EC varied from 85 to $351 \mu \mathrm{S} \mathrm{cm}{ }^{-1}$, these values being similar to fresh low mineralized water. The lowest values were systematically recorded in the river $\left(<100 \mu \mathrm{S} \mathrm{cm}^{-1}\right)$ at the end of the rainy season (4/2010 and 4/2012) and slightly higher (from 110 to $180 \mu \mathrm{S} \mathrm{cm}^{-1}$ ) at the end of the dry or at the beginning of the rainy ones (9/2006, 10/2007, 12/2012, and 11/2013). Puddles and springs showed EC values systematically higher (between 129 and $351 \mu \mathrm{S} \mathrm{cm}^{-1}$ ). The $\mathrm{pH}$ was slightly acid (between 4.7 and 5.9). Eventually, the alkalinity of waters ranged from 0.5 to $3.0 \mathrm{mmol}^{-1}$. Field measurements revealed a gradient distribution among the river, puddle, and spring waters that showed a decrease of temperature and $\mathrm{pH}$ and an increase of EC (Fig. 2).

\section{Equilibrium $\mathrm{CO}_{2}$ partial pressure}

The equilibrium $\mathrm{CO}_{2}$ partial pressure of water $\left(p \mathrm{CO}_{2} \mathrm{eq}\right.$; Table 1; Fig. 2) was calculated from field measured temperatures, $\mathrm{pH}$, and alkalinities according to the relations of Plummer and Busenberg (1982). These values were ranging between 132 and $1196 \mathrm{mbar}(n=18)$, and higher than 3 or 4 orders of magnitude than that of atmospheric $p \mathrm{CO}_{2}$, testifying the intense $\mathrm{CO}_{2(\mathrm{~g})}$ degassing that affects the area. Overall, computed $p \mathrm{CO}_{2}$ eq gradually increased from the river (between 132 and 699 mbar) to puddle (between 507 and 1074 mbar) and to spring (between 730 and 1196 mbar) waters.

\section{Water isotopic signature}

The water stable isotopic compositions showed a large variability since the $\delta^{18} \mathrm{O}$ values were ranging from -17.9 to $-5.0 \%$ and those of $\delta^{2} \mathrm{H}$ from -31.8 and $-11.9 \%$ o $(n=28$; Table 1). In the $\delta^{2} \mathrm{H}$ vs. $\delta^{18} \mathrm{O}$ diagram (Fig. 3), all these waters plot to the left of both Global and Regional Meteoric Water Lines (GMWL: $\delta^{2} \mathrm{H}=8.2 \delta^{18} \mathrm{O}+11.3$; Rozanski et al. 1993 and RMWL: $\delta^{2} \mathrm{H}=8.6 \delta^{18} \mathrm{O}+14.8$; Nivet et al. 2018). They are aligned (Fig. 3 ) all along a pseudo-horizontal line: $\delta^{2} \mathrm{H}=-0.8 \delta^{18} \mathrm{O}-32.9(n=28 ; r=0.77)$, which is noticed as the Shiwaga Water Line (SHI-WL) and does not significantly differ from the " $\mathrm{H}_{2} \mathrm{O}-\mathrm{CO}_{2}$ exchange effect line" proposed at regional RVP scale by Delalande et al. (2011). Along the SHI-WL, two end members can be recognized: (1) the river waters, which plot on or slightly above the MWLs, and (2) the spring waters, which have extremely atypical $\delta^{18} \mathrm{O}$ depletion and slightly enriched in $\delta^{2} \mathrm{H}$. Most of the puddle waters plot between these two end members (Fig. 3).

\section{$\mathrm{CO}_{2}$ gas isotopic signature}

In the Shiwaga gas field, the isotopic composition of $\mathrm{CO}_{2(\mathrm{~g})}$ $\left(\delta^{13} \mathrm{C}-\mathrm{CO}_{2(\mathrm{~g})}\right.$ vs. PDB and $\delta^{18} \mathrm{O}-\mathrm{CO}_{2(\mathrm{~g})}$ vs. V-SMOW; $n=15$; Table 1) was relatively homogeneous with the 
Fig. $3 \delta^{2} \mathrm{H}$ vs. $\delta^{18} \mathrm{O}$ diagram of waters sampled at the Shiwaga gas field: with black circle: springs (S), gray circle: puddles $(\mathrm{P})$ white circle: rivers samples (R), black line: regional meteoric water line (RMWL), gray line: global meteoric water line (GMWL) and dotted line: Shiwaga water line (SHI-WL)

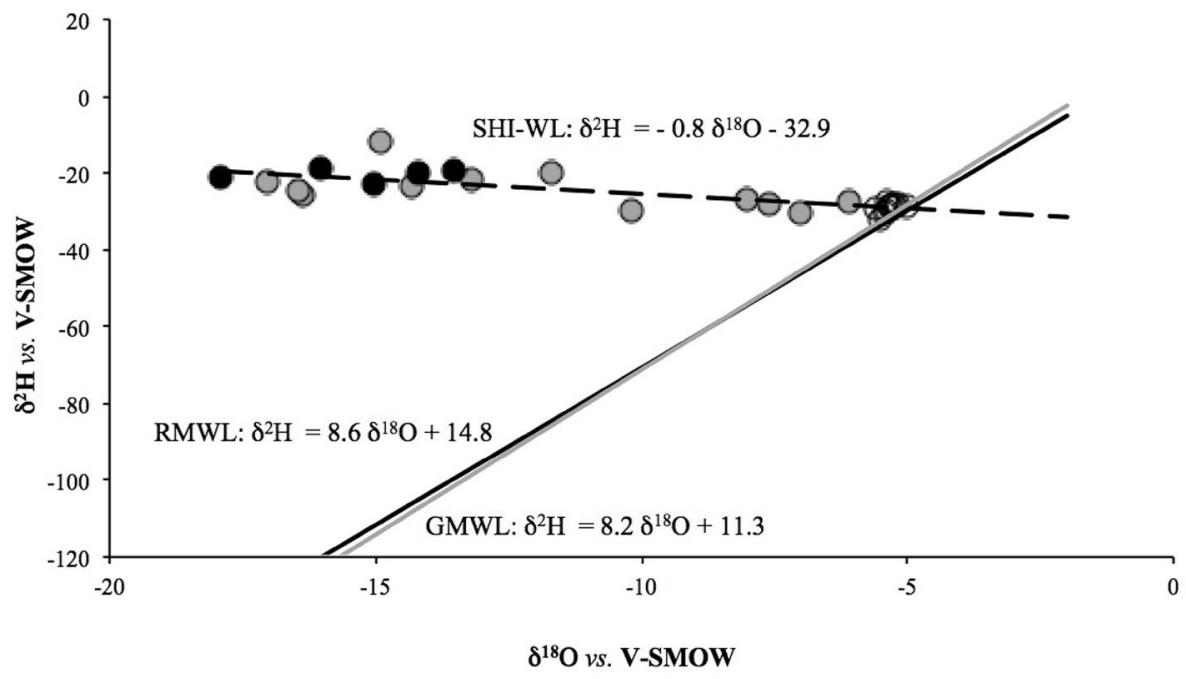

$\delta^{13} \mathrm{C}-\mathrm{CO}_{2(\mathrm{~g})}$ values ranging from -4.1 to $-3.6 \%$ and those of $\delta^{18} \mathrm{O}-\mathrm{CO}_{2(\mathrm{~g})}$ varying from 13.7 to $18.1 \%$. These $\delta^{13} \mathrm{C}-\mathrm{CO}_{2(\mathrm{~g})}$ values $(\approx-3.8 \%$ ) are compatible with a mantle origin of $\mathrm{CO}_{2(\mathrm{~g})}$ as observed in many places along the East African Rift (Darling 1998) and in the RVP (Delalande et al. 2011). The $\delta^{18} \mathrm{O}-\mathrm{CO}_{2(\mathrm{~g})}$ data $(\approx 15 \%)$ are subject to caution due to the inherent difficulty in obtaining representative samples especially because of the fast exchange between $\mathrm{H}_{2} \mathrm{O}$ and $\mathrm{CO}_{2(\mathrm{~g})}$ (Panichi et al. 1977; Gemery et al. 1996). Nevertheless, these values are in the same order of magnitude of deep originated volcanic $\delta^{18} \mathrm{O}-\mathrm{CO}_{2(\mathrm{~g})}$ values calculated in Karolyte et al. (2017). As a whole, the $\mathrm{CO}_{2(\mathrm{~g})}$ isotopic signature of $\delta^{13} \mathrm{C}$ and $\delta^{18} \mathrm{O}$ seems to be compatible with a deep magmatic origin and scarcely affected by isotopic exchanges with subsurface waters, testified by quantitatively high and rapidly uprising $\mathrm{CO}_{2(\mathrm{~g})}$ at the Shiwaga gas field. Furthermore, the $\Delta^{18} \mathrm{O}\left(\mathrm{CO}_{2(\mathrm{~g})}-\mathrm{H}_{2} \mathrm{O}\right)$ values, between 19.3 and $32.3 \%$, are markedly different from those at equilibrium: 40-44\% (calculated between 10 and $30^{\circ} \mathrm{C}$; Brenninkmeijer et al. 1983), suggesting an oxygen isotopic disequilibrium between sampled $\mathrm{H}_{2} \mathrm{O}$ and $\mathrm{CO}_{2(\mathrm{~g})}$.

\section{Discussion}

The isotopic composition measured on the studied waters (Fig. 3) testifies an un-evaporated signature (Gonfiantini 1986). The Shiwaga River waters present a predominant meteoric signature (Nivet et al. 2018) and the spring ones, an atypical composition, characterized by relatively low ${ }^{18} \mathrm{O}$ values. Either river or spring isotopic signatures appear to be more or less stable over time, suggesting relatively steadies state conditions. The puddle waters are aligned along the SHI-WL defined by the two above end members. This linear trend between the two end members is consistent with observed field measurements or calculated $\mathrm{CCO}_{2}$ eq gradients (Fig. 2), suggesting different water sources and/or geochemical processes affecting rivers, puddles, and springs waters. These observations are strongly supported by significant negative correlations between $\delta^{18} \mathrm{O}$ and $\mathrm{EC}(n=26 ; r=0.78)$ and $p \mathrm{CO}_{2} \mathrm{eq}(n=18 ; r=0.75)$ or positive one with $\mathrm{T}(n=28$; $r=0.65)$. The observed ${ }^{18} \mathrm{O}$ disequilibrium between $\mathrm{CO}_{2(\mathrm{~g})}$ and $\mathrm{H}_{2} \mathrm{O}$ is fairly unexpected as exchange between these two phases is known to be fast (Epstein and Mayeda 1953) and might indicate short interaction times. Lécuyer et al. (2009) showed that the time needed to reach oxygen isotope equilibrium between $\mathrm{CO}_{2(\mathrm{~g})}$ and $\mathrm{H}_{2} \mathrm{O}$, under ambient conditions, varies between 4 and $12 \mathrm{~h}$ depending on water salinity. Moreover, the observed $\mathrm{CO}_{2(\mathrm{~g})}-\mathrm{H}_{2} \mathrm{O}$ isotopic disequilibrium, which appears higher in the river samples than that in the springs, may correspond to different interaction times and/ or $\mathrm{CO}_{2(\mathrm{~g})} / \mathrm{H}_{2} \mathrm{O}$ ratio and remind again the two end members of the SHI-WL (Figs. 2, 3). To explain these observations, a conceptual scheme is proposed and considers that water, which flows by gravity, and gas, which flows up cross each other with different flow rates and speeds, inducing different times of interaction between the two phases. The different types of waters are then explained as below:

1. The isotopic composition of spring waters shows an unusual negative shift relative to meteoric waters. Several scenarios may be proposed to clarify these depleted $\delta^{18} \mathrm{O}$ signature. According to the $\delta^{18} \mathrm{O}$ vs. $\delta^{2} \mathrm{H}$ diagram (Fig. 3; D'Amore and Panichi 1987), the most likely hypothesis is that the $\delta^{18} \mathrm{O}-\mathrm{H}_{2} \mathrm{O}$ values of the springs are clearly affected by an isotopic exchange with important amount of $\mathrm{CO}_{2(\mathrm{~g})}$ (Cartwright et al. 2002), in agreement with previous regional study (Delalande et al. 2011). Other mechanism such as precipitation-dissolution reactions, bubble formation, exchange with atmosphere, 
salinity effect, kinetic fractionation, which may affect the $\delta^{18} \mathrm{O}-\mathrm{H}_{2} \mathrm{O}$ (Broecker and Siems 1984; Jähne et al. 1987; Chiodini et al. 2000), cannot likely be considered responsible for such large ${ }^{18} \mathrm{O}$-shift (Karolyte et al. 2017). The assumption of $\mathrm{CO}_{2(\mathrm{~g})}-\mathrm{H}_{2} \mathrm{O}$ isotopic exchange agrees with the observed low spring flow rates and the conspicuous $\mathrm{CO}_{2(\mathrm{~g})}$ up-flow. Numerical geochemical simulations, based on a simplified zero dimensional model and assuming steady state conditions and instantaneous isotopic equilibrium, show that an important $\mathrm{CO}_{2(\mathrm{~g})} / \mathrm{H}_{2} \mathrm{O}$ ratio upper than $0.5 \mathrm{~mol} / \mathrm{mol}$ is required to obtain such an ${ }^{18} \mathrm{O}$-shift. Consequently, the springs are supplied by infiltrated local precipitation with an initial estimated of $-4.1 \%$ in $\delta^{18} \mathrm{O}$ and $-20.3 \%$ in $\delta^{2} \mathrm{H}$ composition from springs deuterium values and the LMWL. Values, which agree with those recorded eastward at Kilasi $\left(33.82^{\circ} \mathrm{E}, 9.12^{\circ} \mathrm{S} ; 1690 \mathrm{~m}\right.$ a.s.1.), $-16.9 \%$ in $\delta^{2} \mathrm{H}$ and $-3.8 \%$ in $\delta^{18} \mathrm{O}$ (Nivet et al. 2015). Once local rainfalls infiltrate, the interaction with the deep-seated $\mathrm{CO}_{2}$ modifies the original $\delta^{18} \mathrm{O}-\mathrm{H}_{2} \mathrm{O}$ values, whereas the pristine hydrogen isotopic composition is maintained. Because of different directions and speeds between gas and water flows, the duration of $\mathrm{CO}_{2(\mathrm{~g})}$ interaction with groundwater is short (some seconds or minutes) inducing low $\delta^{18} \mathrm{O}-\mathrm{CO}_{2}$ variation, whereas water undergoes flowing up $\mathrm{CO}_{2(\mathrm{~g})}$ during longer time (hours, days or weeks) inducing a cumulative $\delta^{18} \mathrm{O}-\mathrm{H}_{2} \mathrm{O}$ depletions down to $\delta^{18} \mathrm{O}$ values of around $-15.3 \%$ (corresponding to a $\Delta^{18} \mathrm{O}-\mathrm{H}_{2} \mathrm{O}$ shift around $-11.2 \%$ ). At the spring temperature $\left(13.9^{\circ} \mathrm{C}\right)$, the $\Delta^{18} \mathrm{O}\left(\mathrm{CO}_{2(\mathrm{~g})}-\mathrm{H}_{2} \mathrm{O}\right)$ is expected to be around 42.5\% (Bottinga 1968), whereas a mean value of $30.5 \%$ was measured (Table 1). This suggests that either time interaction between groundwater and gas is too short to reach isotopic equilibration or spring waters $\left(\delta^{18} \mathrm{O} \approx-15 \%\right.$ o) result from a mixing, in 45 and $55 \%$ proportions, between (1) $\mathrm{CO}_{2(\mathrm{~g})}$ equilibrated water $\left(\delta^{18} \mathrm{O} \approx-27 \% \circ\right)$ and $(2)$ rainfall water unaffected by $\mathrm{CO}_{2(\mathrm{~g})}\left(\delta^{18} \mathrm{O} \approx-4 \%\right.$ ), respectively.

2. The river is supplied by higher altitude rainfalls. Its composition at the Shiwaga gas field upstream is estimated, from river water $\delta^{2} \mathrm{H}$ values $(n=11)$ and LMWL, at -5.1 and $-28.9 \%$ in $\delta^{18} \mathrm{O}$ and $\delta^{2} \mathrm{H}$, respectively. Then, due to the rapid interaction time of river water with uprising $\mathrm{CO}_{2(\mathrm{~g})}$ (estimated from river flow at around one minute) and lower $\mathrm{CO}_{2(\mathrm{~g})} / \mathrm{H}_{2} \mathrm{O}$ ratio, river waters undergo a small $\delta^{18} \mathrm{O}$ depletion: ca. $-0.2 \%$.

3. The puddles (located nearby or in the riverbed) are fed by either local rainfall, groundwater and/or river flood. The water isotopic composition is then characterized by large variations that are more or less between those of the spring and river end members.
To summarize, the water deuterium variations between river and spring end members $\left(\Delta^{2} \mathrm{H}-\mathrm{H}_{2} \mathrm{O}\right.$ of $-8.6 \%$ ) are induced by different waters origins, local, or higher rainfall in agreement with potential altitudinal rainfall isotopic gradient (Yurtsever and Gat 1981). The oxygen 18 variations are explained by different interaction times and $\mathrm{CO}_{2(\mathrm{~g})} / \mathrm{H}_{2} \mathrm{O}$ ratio between waters and an up flowing deep $\mathrm{CO}_{2(\mathrm{~g}}$. The latter means that $\mathrm{CO}_{2(\mathrm{~g})}-\mathrm{H}_{2} \mathrm{O}$ interaction are being responsible for high observed $p \mathrm{CO}_{2}$ eq and $\mathrm{EC}$ values and relatively low $\mathrm{pH}$ between river and spring waters.

\section{Conclusions and perspectives}

This study combines, with a spatiotemporal approach, field observations and water and gas geochemical data from several surveys (from 2006 to 2015) carried out at the Shiwaga gas field (Fig. 1). Evidences of a relative stable system with high geochemical spatial variability of water types were highlighted; a result that cannot be shown by a single field survey. Field observations and measurements show a large amount of $\mathrm{CO}_{2(\mathrm{~g})}$ emanations, distributed among river, puddle, and spring. The $\delta^{13} \mathrm{C}-\mathrm{CO}_{2(\mathrm{~g})}$ and $\delta^{18} \mathrm{O}-\mathrm{CO}_{2(\mathrm{~g})}$ signatures are stable and typical of a mantle source. The water isotopic signatures revealed that river waters originated from high elevation rainfalls, whereas spring and puddle waters are clearly affected by isotopic exchange between $\mathrm{H}_{2} \mathrm{O}$ and $\mathrm{CO}_{2}$ as large deep $\mathrm{CO}_{2(\mathrm{~g})}$ amount induced a decrease of $\delta^{18} \mathrm{O}-\mathrm{H}_{2} \mathrm{O}$ and $\mathrm{pH}$ as well as an increase of $\mathrm{EC}$ and $p \mathrm{CO}_{2}$ eq up to 1196 mbar (Fig. 2). Consequently, on the $\delta^{2} \mathrm{H}$ vs. $\delta^{18} \mathrm{O}$ diagram (Fig. 3), the spring and puddle waters plot to the left of the meteoric water lines and a significant $\delta^{18} \mathrm{O}$ shift (up to $11.2 \%$ ) is observed. Such a shift can only be reached if involved mantle $\mathrm{CO}_{2(\mathrm{~g})}$ fluxes are high enough (compatible with the minimum of $100 \mathrm{~kg} \mathrm{~m}^{-2} \mathrm{~h}^{-1}$ measured over Shiwaga River) and if the original isotopic compositions of subsurface waters are somewhat depleted as observed at low latitudes. Nevertheless, comparable shift was already highlighted in the RVP on the Kiejo volcano flank (Delalande et al. 2011) and comparable flux in the East African Rift System (Vaselli et al. 2002; Smets et al. 2010), as well as in other geodynamic context (Chiodini et al. 2000, 2012; Frondini et al. 2009). These $\mathrm{CO}_{2(\mathrm{~g})}$ emanations represent an environmental hazard but also constitute a regional resource as, on both Rungwe and Kiejo volcanoes, this natural $\mathrm{CO}_{2(\mathrm{~g})}$ is conditions and commercializes, especially for soda industries (Delalande et al. 2011). Fortunately, the noise caused by the river bubbling activity warns against the area and its hazards, while silent dry gas fields do not. An inventory and a monitoring of these sites, up to now poorly explored, appear essential for policy security in regard to their impact on the local flora, wildlife and population. Finally, this study 
invites to investigate in detail the Shiwaga gas field and the region with multidisciplinary approaches to (1) quantify more precisely the involved flux and (2) to better define the Poroto-Rungwe geothermal field potential as well as natural hazards.

Acknowledgements We acknowledge the support of the Institute of Resource Assessment (IRA) of University of Dar es Salaam. The Masoko Lwifwa community is thanked for assisting us during fieldwork and Aurélie Noret for her help in laboratory work. We express our appreciation to Dr. Orlando Vaselli for his helpful comments on the first versions of the manuscript. This research was supported by the CLEHA project of the ECLIPSE program (Institut National des Sciences de l'Univers), the French Embassy and the Tanzanian Commission of Science and Technology (COSTECH). This is a publication of the Rungwe Environmental Science Observatory Network (RESON).

\section{References}

Barry PH, Hilton DR, Fischer TP, de Moor JM, Mangasini F, Ramirez C (2013) Helium and carbon isotope systematics of cold "mazuku" $\mathrm{CO}_{2}$ vents and hydrothermal gases and fluids from Rungwe Volcanic Province, southern Tanzania. Chem Geol 339:141-156

Bottinga Y (1968) Calculation of fractionation factors for carbon and oxygen isotopic exchange in the system calcite-carbon dioxidewater. J Phys Chem 72(3):800-808

Branchu Ph, Bergonzini L, Delvaux D, De Batist M, Golubev V, Benedetti M, Klerkx J (2005) Tectonic, climatic and hydrothermal control on sedimentation and water chemistry of northern Lake Malawi (Nyasa), Tanzania. J Afr Earth Sci 43:433-446

Brenninkmeijer CAM, Kraft P, Mook WG (1983) Oxygen isotope fractionation between $\mathrm{CO}_{2}$ and $\mathrm{H}_{2} \mathrm{O}$. Chem Geol 1:181-190

Broecker HC, Siems W (1984) The role of bubble for gas transfer from water to air at higher wind speeds experiments in the wind-wave facility in Hamburg. In: Brutsaert W, Jirka GH (eds) Gas transfer at water surfaces, vol 2. Springer, Dordrecht, pp 229-238

Cartwright I, Weaver T, Tweed S, Ahearne D, Cooper M, Czapnik K, Tranter J (2002) Stable isotope geochemistry of cold $\mathrm{CO}_{2}$-bearing mineral spring waters, Daylesford, Victoria, Australia: sources of gas and water and links with waning volcanism. Chem Geol 185:71-91. https://doi.org/10.1016/S0009-2541(01) 00397-7

Chiodini G, Allard P, Caliro S, Parello F (2000) ${ }^{18} \mathrm{O}$ exchange between steam and carbon dioxide in volcanic and hydrothermal gases: implication for the source of water. Geochim Cosmochim Acta 64(14):2479-2488

Chiodini G, Caliro S, De Martino P, Avino R, Gherardi F (2012) Early signals of new volcanic unrest at Capi Flegrei caldera ? Insights from geochemical data and physical simulations. Geology 40:943-946

D'Amore F, Panichi C (1987) Geochemistry in geothermal exploration. Appl Geo Therm 9:69-89

Darling WG (1998) Hydrothermal hydrocarbon gases: 2, application in the East African Rift system. Appl Geochem 13(7):825-840

De Moor JM, Fischer TP, Sharp ZD, Hilton DR, Barry PH, Mangasini F, Ramirez C (2013) Gas chemistry and nitrogen isotope compositions of cold mantle gases from Rungwe Volcanic Province, southern Tanzania. Chem Geol 339:30-42

Delalande M, Bergonzini L, Branchu Ph, Filly A, Williamson D (2008) Hydroclimatic and geothermal controls on the salinity of Mbaka
Lakes (SW Tanzania): limnological and paleolimnological implications. J Hydrol 359:274-286

Delalande M, Bergonzini L, Gherardi F, Guidi M, André L, Abdallah I, Williamson D (2011) Fluid geochemistry of natural manifestations from the Southern Poroto-Rungwe hydrothermal system (Tanzania): preliminary conceptual model. J Volcanol Geotherm Res 199(1-2): 127-141, ISSN 0377 - 0273

Delalande-Le Mouëllic M, Gherardi F, Williamson D, Kajula S, Kraml M, Noret A, Abdallah I, Mwandapile E, Massault M, Majule A, Bergonzini L (2015) Hydrogeochemical features of Lake Ngozi (SW Tanzania). J Afr Earth Sci 103:153-167 (ISSN 1464-343X)

Ebinger C, Klerkx J, Delvaux D, Wüest A (1993) Evaluation of natural hazards in the northern part of the Malawi rift (Tanzania). Mus Roy Afr Centr Tervuren (Belg) Dépt Géol Min Rapp Ann 1991-1992:83-86

Epstein S, Mayeda T (1953) Variation of $\mathrm{O}^{18}$ content of waters from natural sources. Geochim Cosmochim Acta 4:(5):213-224

Fontijn K, Ernst GGJ, Elburg MA, Williamson D, Abdallah E, Kwelwa S, Mbede E, Jacobs P (2010) Holocene explosive eruptions in the Rungwe Volcanic Province, Tanzania. J Volcanol Geotherm Res 196(1-2):91-110 (ISSN 0377-0273)

Fontijn K, Williamson D, Mbede E, Ernst GGJ (2012) The Rungwe volcanic province, Tanzania: a volcanological review. J Afr Earth Sci 63:12-31. (ISSN 1464-343X)

Frondini F, Caliro S, Cardellini C, Chiodini G, Morgantini N (2009) Carbon dioxide degassing and thermal energy release in the Monte Amiata volcanic-geothermal area (Italy). Appl Geochem 24(5):860 875

Gemery PA, Trolier M, White JWC (1996) Oxygen isotope exchange between carbon dioxide and water following atmospheric sampling using glass flasks. J Geophys Res 101:14415-14420

Gonfiantini R (1986) Environmental isotopes in lake studies. In: Fritz $\mathrm{P}$, Fontes JC (eds) The terrestrial environment, B, handbook of environmental isotope geochemistry. Elsevier, Amsterdam, pp 113-168. https://doi.org/10.1016/B978-0-444-90842225-5.50008 -5 (Chap. 3)

Hards VL (2005) Volcanic contributions to the global carbon cycle. British Geological Survey, Nottingham, UK (British Geological Survey Occasional Publication, No. 10)

Harkin DA (1960) The Rungwe volcanics at the northern end of Lake Nyasa, Mem II. Geol Surv Tanganyika, Dodoma

Hilton DR, Halldórsson SA, Barry PH, Fischer TP, de Moor JM, Ramirez CJ, Mangasini F, Scarsi P (2011) Helium isotopes at Rungwe Volcanic Province, Tanzania, and the origin of East African Plateaux. Geophys Res Lett 38:L21304. https://doi. org/10.1029/2011GL049589

Jähne B, Münnich KO, Bosinger R, Dutzi A, Huber W, Libner P (1987) On parameters influencing air-water gas exchange. J Geophys Res 92:1937-1949

Kabaka KT, Mnjokava TT, Kajugus SI (2016) Geothermal development in Tanzania a country update. In: Proceedings 6th African Rift geothermal conference, Addis Ababa, Ethiopia

Kalerkamp U, Schaumann G, Ndonde PB, Chiragwile SA, Mwano JM (2010) Surface exploration of a viable geothermal resource in Mbeya Area, SW Tanzania. Part II: geophysics. In: Proceedings, 4th world geothermal congress, Bali, Indonesia

Karolyte R, Serno S, Johnson G, Gilfillan S (2017) The influence of oxygen isotope exchange between $\mathrm{CO}_{2}$ and $\mathrm{H}_{2} \mathrm{O}$ in natural $\mathrm{CO}_{2}$-rich spring waters: implications for geothermometry. Appl Geochem. https://doi.org/10.1016/j.apgeochem.2017.06.012

Kraml M, Mnjokava TT, Mayalla JW, Kabaka K (2010) Surface Exploration of a viable geothermal resource in Mbeya Area, SW Tanzania. Part II: geochemistry. In: Proceedings, 4th world geothermal congress, Bali, Indonesia 
Kraml M, Ochmann N, Leible D, Kling T, Chiragwile SA, Jodocy M, Kreuster H and GPT exploration Team (2014) Results of the pre-feasibility study on Ngozi geothermal project in Tanzania. In: Proceedings of the 5th African Rift geothermal conference, Arusha, Tanzania

Lécuyer C, Gardien V, Rigaudier T, Fourel F, Martineau F, Cros A (2009) Oxygen isotope fractionation and equilibration kinetics between $\mathrm{CO}_{2}$ and $\mathrm{H}_{2} \mathrm{O}$ as a function of salinity of aqueous solutions. Chem Geol 264:122-126

Nivet F, Bergonzini L, Diemer L, Mathé P-E, Kajula S, Ngingo P, Mwasomba S, Noret A, Majule A, Williamson D (2015) RESON: 3 -year records of rainfall isotopic composition from 3 stations of the Rungwe Volcanic Province (SW Tanzania). In: tropical deserts and lakes through time-symposium in memory of Françoise Gasse, 2015, Aix-en-Provence, France, July

Nivet F, Bergonzini L, Mathé P-E, Noret A, Monvoisin G, Majule A, Williamson D (2018) Influence of the balance of the Intertropical Front on seasonal variations of rainfall isotopic compositions at Kisiba Masoko (Rungwe Volcanic Province, SW, Tanzania). Isotopes Environ Health Stud. https://doi.org/10.1080/10256 016.2018.1443923

Panichi C, Ferrara GC, Gonfiantini R (1977) Isotope geothermometry in the Larderello geothermal field. Geothermics 5:81-88

Plummer LN, Busenberg E (1982) The solubilities of calcite, aragonite and vaterite in $\mathrm{CO}_{2}-\mathrm{H}_{2} \mathrm{O}$ solutions between 0 and $90{ }^{\circ} \mathrm{C}$, and an evaluation of the aqueous model for the system $\mathrm{CaCO}_{3}-\mathrm{CO}_{2}-$ $\mathrm{H}_{2} \mathrm{O}$. Geochim Cosmochim Acta 46(6):1011-1040. https://doi. org/10.1016/0016-7037(82)90056-4

Rozanski K, Araguas-Araguas L, Gonfiantini R (1993) Isotopic patterns in modern global precipitation. In: Swart PK, Lohmann KC, McKenzie J, Savin S (eds) Climate change in continental isotopic records. American Geophysical Union, Washington DC, pp 1-36

Smets B, Tedesco D, Kervyn F, Kies A, Vaselli O, Yalire MM (2010) Dry gas vents ("mazuku") in Goma region (North Kivu, Democratic republic of Congo): formation and risk assessment. J Afr Earth Sci 58(5):787-798

Sorey M, Farrar C, Gerlach T, McGee K, Evans W, Colvard E, Hill D, Bailey R, Rogie J, Hendley IIJ, Stauffer P (2000) Invisible $\mathrm{CO}_{2}$ gas killing trees at Mammoth Mountain, California U.S. Geological Survey Fact Sheet, pp 172-96

Vaselli O, Capaccioni B, Tedesco D, Tassi F, Yalire MM, Kasareka MC (2002) The "evil's winds" (mazukus) at Nyiragongo Volcano (Democratic Republic of Congo). Acta Vulcanol 14-15:123-128

Yurtsever Y, Gat JR (1981) Atmospheric waters. In: Gat JR, Gonfiantini R (eds) Stable isotope hydrology: deuterium and oxygen-18 in the water cycle, vol 210. International Atomic Energy Agency, Vienna (Austria), pp 103-142 